\author{
Magda Ševčíková, Jarmila Panevová \\ Charles University \\ Institute of Formal and Applied Linguistics
}

\title{
Derivation of Czech verbs and the category of aspect
}

Ke y w ord s: derivation; inflection; aspect; prefix; suffix

Klíc č ov á s lov a: odvozování; flexe; slovesný vid; předpona; př́pona

\section{Introduction}

The research into the category of aspect in Czech has reflected on aspectology of other Slavic languages, particularly of Russian and Polish, but it remained mostly unaffected by the distinction between grammatical vs. lexical aspect discussed esp. in approaches that are not limited to Slavic languages. ${ }^{1}$

The discussion in Czech linguistics was centred around the definition of aspect as a grammatical or lexical category, on the one hand, and around the

1 Grammatical aspect (or alternatively "morphological aspect", "viewpoint aspect", or "outer aspect"; cf. Verkuyl 1993, Smith 1991, Mel'čuk 1994, or de Swart 2012) is referred to as "verbal aspect" or just "aspect" in Czech. The issues subsumed under the lexical aspect (also "aspectual class", "situation aspect", or "inner aspect"; cf. Filip 2012) were discussed under the terms Aktionsart and telicity (Isačenko 1960b, Daneš 1971, Komárek 2006). Cf. also the application of Vendler's approach (1957) to Czech and other Slavic languages by Kučera (1983) and Eckert (1984). The diachronic perspective on aspect in Slavic languages and beyond is taken by Němec (1958), Wiemer - Seržant (2017), or Bybee et al. (1994), cf. also the respective chapters in Comrie (1976) or Dahl (1985). 
morphemic structure of pure aspectual pairs, on the other. After a brief summary of these topics (Section 2), we focus on a rather neglected issue of the Czech aspectology, namely, on the relation of aspect to derivation. In Section 3, we advocate a broad approach to aspect by seeing it as a category whose meanings belong to the inflectional morphology of verbs while formal means fall under the scope of derivational morphology. We argue that the formation of aspectual counterparts is an integral part of the verb-to-verb derivation in Czech. In Section 4, aspect is presented as one of the features used for organizing verbs in DeriNet, a large specialized database of Czech derivation.

\section{The category of aspect in Czech}

\subsection{Aspect as a grammatical vs. lexical category}

In Czech verbs, aspect is expressed by affixes used in derivation (i.e. of agglutinative nature) whereas person, number and other verbal categories are expressed cumulatively by inflectional suffixes and/or endings (in some forms with auxiliary forms of the verb by't 'to be'); see a form of a perfective verb in ex. (1) and of its imperfective counterpart in ex. (2).

(1) chyt-i-l-a '(she) catched.pf' catch-PF-PST.IND.ACT-3.SG.FEM

(2) chyt-a-l-a '(she) catched.impf' catch-IMPF-PST.IND.ACT-3.SG.FEM

The debate over aspect in Czech linguistics has been influenced by the fact that derivation is not considered to be a part of morphology in grammar books of Czech. Being excluded from morphology and, thus, from the grammatical description, derivation is looked upon as a part of word-formation which is seen as a transition zone between grammar and lexicon; derivational means are classified as non-grammatical means (Bednaříková 2009:24). ${ }^{2}$

2 Morphology is then limited to inflectional morphology which is reflected by the identification of "morphology" and "inflection" in grammar books of Czech. 
As aspect of Czech verbs is expressed by derivational morphemes, it was probably the exclusion of derivation from grammar which did not allow defining aspect simply as a grammatical (morphological) category but as a "morphological-lexical" category of verbs in the representative grammar of Czech (Komárek et al. 1986:179ff). A similar oscillation between grammar and lexicon is documented in all other grammar books of Czech. Nevertheless, the more recent ones come closer to the grammatical approach (cf. Cvrček et al. 2013:245, Štícha et al. 2013:440). Similarly, Nübler et al. (2017) state explicitly that a change in aspect leads to creating forms of the same verb lexeme. A clearly grammatical interpretation is also documented in a few older studies (Kopečný 1962, or Isačenko 1960a).

In contrast to the lack of consensus in the definition of aspect, the descriptions agree that two groups of imperfective and perfective verbs are to be discerned. ${ }^{3}$ Imperfectivity is described as a continuation of an event (without respect to its completion) whereas perfectivity means completion or boundedness of an event (Panevová et al. 1971; Nübler et al. 2017). If imperfectivity vs. perfectivity concern the same event or, stated differently, if the imperfective verb and its perfective counterpart share the same lexical meaning and differ just in the aspect, they form a pure aspectual pair. The imperfective verb is considered to be the unmarked member of the aspectual opposition by Mathesius (1947), Isačenko (1960a), Kopečný (1962), or Jakobson (1971). The opposite position, in which the perfective is seen as the unmarked member, is taken by Wierzbicka (1967) or Bogusławski (2003, 2014).

\subsection{Morphemic structure of pure aspectual pairs in Czech}

In the debate over the morphemic structure of verbs in pure aspectual pairs, i.e. pairs of an imperfective and a perfective verb which differ only in suffixes, are considered the core type; these include pairs of simplex verbs (cf. chytit - chytat in ex. (1) and (2) and ex. (3a)) as well as pairs of prefixed

${ }^{3}$ Kopečný's proposal (1962) to include the iterativeness as the third value into the category of aspect was admitted by Komárek et al. (1986:180) as a part of "aspect in a broader sense". Otherwise, iterativeness is subsumed under the category of Aktionsart (Poldauf 1964 and others). Verbs of both Czech and foreign origin which are marked as biaspectual in the dictionaries of Czech (Havránek 1960-1971) are disambiguated by the context (Jindra 2008). 
verbs (i.e. a prefixed verb and a secondary imperfective derived by suffixation; (3b)).

(3) (a) skák-a-t 'to jump.impf' - skoč-i-t 'to jump.pf'

(b) $v y$-skoč-i-t 'to jump up.pf'-vy-skak-ova-t 'to jump up.impf'

The second type of pure aspectual pairs which is constituted by an imperfective simplex and a prefixed perfective (4) is accepted in most grammar books of Czech and some other resources (cf. Nübler et al. 2017, Nübler 1992, Eckert 1984, or Kopečný 1962). However, the Czech lexicographic practice is inconsistent in this respect. ${ }^{4}$

(4) vař-i-t 'to cook.impf' - u-vař-i-t 'to cook.pf'

Poldauf (1954) classified verbal prefixes into three classes: pure perfectivizing prefixes which are rare (4), subsumption prefixes whose lexical semantics overlaps with a semantic feature of the prefixless verb (cf. the prefix prí- in (5a) that shares the feature of "approaching something" with the base verb; cf. also Esvan 2007, 2014), and prefixes that cause semantic shifts (5b). In grammar books of Czech, a simplified classification of prefixes into pure perfectivizing prefixes (as in (4)) and those causing lexical shifts (both (5a) and (5b)) is found.

(5) (a) bliž-i-t se 'to approach.impf' - při-bliž-i-t se 'to approach/come close.pf'

(b) lep-i-t 'to glue.impf' - při-lep-i-t 'to attach by gluing.pf'

${ }^{4}$ In the representative dictionaries (such as Slovnik spisovného jazyka českého, Havránek et al. 1961-1970, and Slovník spisovné češtiny, Filipec et al. 1998), the relation between the verbs in (4) as well as between vidèt 'to see.impf' and uvidèt 'to see.pf' is reflected in the entry of the perfective member (cf. "uvařit dok. k vařit" and "uvidět dok. k vidět" in Filipec et al. 1998:478f) while for napsat 'to write.pf' information about its imperfective counterpart is missing. 
Prefixed verbs as pure aspectual counterparts of prefixless imperfectives were rejected by Isačenko $(1960 \mathrm{~b})^{5}$ who interpreted all prefixed perfectives as exhibiting a semantic shift, belonging rather to Aktionsart; cf. also Komárek (2006:194f, originally published as Komárek 1984), Kuryłowicz (1932) and Grzegorczykowa et al. (1984:54ff) for Polish, Karcevskij (1927:107) from the perspective of Russian, or Maslov (1959) for Bulgarian.

\section{Aspectual pairs as a part of the verb-to-verb derivation}

\subsection{Derivation as a part of morphology}

Some of the controversies reported above might be overcome by accepting the broad approach to morphology including both inflection and derivation. Aspect is then definable as a morphological (grammatical) category that belongs to the inflectional meanings of verbs but is formally marked by affixes falling under the scope of derivational morphology (cf. the respective discussion for Polish by Bloch-Trojnar 2013:209ff). Nevertheless, even within the broad grammatical approach, it will not be easy to delimit the boundaries between the inflectional and derivational paradigm of the verbs in a pure aspectual pair, esp. to clarify whether one of the aspectual counterparts (and which one) is a part of the inflectional paradigm of the other one, or whether they are separate lexemes.

\subsection{Formation of aspectual pairs as derivation}

The fact that the category of aspect is expressed by prefixes and suffixes used in derivation is reflected by terms describing the relation between pure aspectual counterparts. Here we apply the derivational perspective consistently and analyse the pairs as consisting of a verb formed from another verb through affixation. Based on the general assumptions that affixed words are derived from their affixless counterparts and that base words are semantically broader than the derivatives (Dokulil 1962:109, Furdík 1978, Booij et al.

5 Isačenko's position was in line with his approach to Russian and Slovak (Isačenko 1960a), but is considered minor, even in Russian linguistics (cf. Janda - Lyashevskaja 2011, Dickey - Janda 2015). 
2000:866), ${ }^{6}$ we compare the morphemic structure and meaning of the members of pure aspectual pairs in order to identify the direction of the relation. The two types of pure aspectual pairs (i.e. formed by suffixes and by prefixes) fall into three groups:

(i) pairs of verbs that both have a suffix but a different one: the verbs are interpreted as results of replacing a suffix by another one (resuffixation); cf. two simplex verbs in (3a) and in (6), but also the prefixed perfective and the secondary imperfective in (3b) or in (7). ${ }^{7}$ As the verbs in the pair are of the same morphemic complexity, the direction of derivation has to be determined according to other features (esp. meaning and/or corpus frequency; cf. Sect. 4.2). In some cases, the resulting classification, for instance, when the perfective (as semantically primary) becomes the base of the imperfective derivative, may contradict the hypothesis of unmarkedness of imperfectives in aspectual pairs (see Sect. 2.1);

(6) (a) ház-e-t 'to throw.impf' - hod-i-t 'to throw.pf'

(b) štěk-a-t 'to bark.impf' - štěk-nou-t 'to bark.pf'

(c) kup-ova-t 'to buy.impf' - koup-i-t 'to buy.pf'

(7) po-škod-i-t 'to damage.pf' - po-škoz-ova-t 'to damage.impf'

(ii) pairs in which one of the verbs has an extra suffix as compared to the other verb, cf. the simplex perfective verb and the corresponding suffixed imperfective in (8), some of the secondary imperfectives (9) also fall under this type. With respect to a common word-formation processes in Czech, formation of these pairs is to be interpreted as adding a suffix to a simplex perfective verb (suffixation), rather than de-

${ }^{6}$ In general, the word that has a simpler morphemic structure is expected to have a broader, less specific meaning and thus to be the base word. There are a few counterexamples in derivation in Czech such as action nouns derived from verbs by the zero suffix (e.g. běhat 'to run' - běh 'run').

${ }^{7}$ Cf. the analysis by Kuznetsova - Sokolova (2016) for Russian who discusses aspectual triplets consisting of a perfective verb with two imperfective correlates, a primary imperfective and a secondary imperfective. 
-suffixation (of more complex imperfectives), which is rare in Czech; the former and preferred interpretation again speaks in favour of the unmarkedness of perfectives.

(8) dá-t 'to give.pf' - dá-va-t 'to give.impf'

(9) pře-prac-ova-t 'to remake.pf' - pre-prac-ov-áv-a-t 'to remake.pf'

(iii) pairs of verbs that differ in the prefix:

here, the prefixless imperfective and the corresponding prefixed perfective have a different morphemic complexity (cf. ex. (4) and (10)). The prefixless imperfective is considered to be the base for the prefixed perfective, which corresponds to the assumed unmarkedness of the imperfective.

(10) (a) dèl-a-t 'to do.impf' - u-děl-a-t 'to do.pf'

(b) pros-i- $t$ 'to ask.impf' - po-pros-i- $t$ 'to ask.pf'

\subsection{Ambiguity of aspectual affixes}

Most of the suffixes and prefixes used in the formation of aspectual counterparts are ambiguous. They are attested in other types of derivation which might be, but do not need to be connected with the change in aspect. In addition to the suffixation in aspectual pairs (types (i) and (ii) in Sect. 3.2), suffixes are used to derive iterative verbs from both prefixless and prefixed imperfectives (11). Besides the formation of prefixed perfective counterparts from simplex imperfectives (type (iii)), prefixes are used to change the lexical meaning of the base verb, causing either radical shifts (12), or slight modifications (see different types of Aktionsart in (13)). In (13c), the Aktionsart feature is added without changing the aspect.

(11) (a) skák-a-t 'to jump.impf' - skák-áv-a-t 'to be used to jump.impf' (b) při-cház-e-t 'to come.impf' - při-cház-ív-a-t 'to be used to come. impf' 
(12) (a) $j-i-t$ 'to go.impf' $-n a-j-i-t$ 'to find.pf'

(b) věd-ě-t 'to know.impf' - po-věd-ě-t 'to tell.pf'

(13) (a) mal-ova-t 'to paint.impf' - do-mal-ova-t 'to finish painting.pf'

(b) vy-táh-nou-t 'to pull up.pf' - po-vy-táh-nou-t 'to pull up a little.pf'

(c) $s k o c ̌-i-t$ 'to jump.pf' - vy-skoč-i-t 'to jump out.pf'

The pure perfectivizing function is fulfilled by different prefixes with different bases; cf. (10a) vs. (10b). A prefix that has the pure perfectivizing function with a particular base can change the meaning if added to another base; cf. (10b) vs. (12b) and (13b). If a particular verb root is compatible with more prefixes (up to 20 different prefixes are attested with a single root in the data), at most one of the competing prefixes is expected to have the pure perfectivizing function. Verbs with pure perfectivizing prefixes are supposed not to serve as bases for secondary imperfectivization (Grepl et al. 2000:318ff and other). The lack of a secondary imperfective is thus considered to be a criterion for identification of the pure perfectivizing prefix among other prefixes attested with the same base (in ex. (4) *uvarovat cannot be derived from $u v a$ rit 'to cook.pf', but cf. (14)).

(14) vař-i- $t$ 'to cook.impf' > do-vař-i-t 'to finish cooking.pf' $>d o-v a \check{r}-$ -ova- $t$ 'to finish cooking.impf'

\section{The role of aspect in modelling derivation in the DeriNet database}

\subsection{The task of organizing verbs in the derivational database}

Within our task of organizing derivationally related verbs in a large language resource specialized in Czech derivation, the DeriNet database (Ševčíková - Žabokrtský 2014; http://ufal.mff.cuni.cz/derinet), we dealt with more than 50 thousand verbs (the pure aspectual pairs are represented as two separate units) which are a part of a total of 1 million lexemes (nouns, adjectives, verbs, and adverbs). ${ }^{8}$

${ }^{8}$ DeriNet is based on the MorfFlex CZ dictionary (Hajič - Hlaváčová 2013), which covers a major part of the lexicon of Czech including proper names, archaic words, low- 
In DeriNet, the lexemes that share a common root are put together and organized according to their morphemic complexity from the simplest to the most complex ones so that they form an oriented graph. In spite of the disadvantages of modelling derivational relations as directed (cf. Bauer 1997, or Booij 2008), we use the oriented structures as a basic model that corresponds to the concept of word-formation rows and nests (Dokulil 1962:13). This simple concept makes it possible to organize massive amounts of material in a unified way.

The organization of verbs in DeriNet was treated as a separate task due to several specific features of verbal derivation in Czech, as compared to the other part-of-speech categories. First of all, verbs are mostly derived from other verbs, whereas other lexemes are often derived across the part-of-speech boundaries. Secondly, while in general, suffixation is the most productive type of derivation in Czech, prefixation predominates over suffixation in the derivation of verbs (Dokulil 1962, Uher 1971, Štekauer et al. 2012). Thirdly, the same root morpheme, mostly attested in two or more allomorphs, is often shared by several dozen verbs (Ziková 2015). Last but not least, derivationally related verbs differ in meaning and/or in aspect.

\subsection{Identifying and organizing derivationally related verbs}

The task consisted of three subsequent subtasks. Verbs that share the same root morpheme (the term "derivational family" is used here; e.g. Blevins 2016) were put together first. After that, base candidates were suggested by a semiautomatic procedure. Finally, a set of simple rules was applied to organize verbs within derivational families coherently across the lexicon of Czech.

Most of the verbal roots of Czech origin have two or more allomorphs. In prefixation of verbs, a single vowel alternation is documented in Czech, namely the á:a alternation in the root morpheme (psát 'to write.impf' - napsat 'to write.pf', znát 'to know.impf'- poznat 'to know.pf' and few other), whereas even the same root may undergo different alternations when combined with different suffixes (see ex. (3)). A set of basic heuristics and, importantly, existing data resources (esp. Lopatková et al. 2017) were used to identify all at-

-frequency words and automatically generated coinages without respect to whether they are attested in a corpus. 
tested allomorphs of the particular roots, taking into account both formal features and lexical ambiguity; cf. the allomorphs skoč, skák, and skak in ex. (3) and Fig. 1.

In order to organize the verbs within particular derivational families according to their morphemic complexity, an automatic procedure was applied to identify potential base verbs for each verb so that they differed in a minimal set of formal features. The procedure consisted of two mutually overlapping steps:

- prefixed verbs, without regard to the function of the prefix, were identified by means of a list of verbal prefixes that was compiled for this task. The prefix was mechanically separated from the verb and the remaining string compared with the verbs in the derivational family (taking also the $a: a$ alternation into account). If such prefixless counterpart was available, it was marked as a potential base for the prefixed verb;

- pairs of verbs that are formally identical except for the suffixes were identified by a simple string-wise comparison of the verbs. If a verb differed from another verb just in the suffix (including both the suffix-replacement and suffix-adding types), it was considered to be a potential base word.

By means of these steps, more than a single base candidate might be suggested for some verbs; cf. rozpracovat 'to elaborate.pf' and pracovávat 'to be used to work.impf' as the base candidates for rozpracovávat 'to elaborate.impf'. The following rules were applied semiautomatically and the output was checked manually, so that a consistent annotation was achieved across the data:

(a) prefixed perfectives were considered to be derived from prefixless imperfectives,

(b) verbs with multiple prefixes were linked to a prefixed verb that has one prefix less; ${ }^{9}$

(c) secondary imperfectives were represented as derivatives of prefixed perfectives. The rule was applied when a prefixless counterpart did not exist (e.g. *skakovat for vyskakovat in (3b)) as well as when it existed

9 Verbs that must be modelled as the results of adding more prefixes in a single step (because the verb with one prefix less, i.e. *posednout, is not attested) are minor in Czech; e.g. popo- in poposednout 'to move on a bit.pf'. 
(cf. the above mentioned verb rozpracovávat was linked to rozpracovat, not to pracovávat);

(d) iteratives were linked to respective imperfective verbs;

(e) in pairs of simplex verbs with different suffixes (mainly aspectual counterparts but also pairs with the same aspect), the decision which of the verbs is the derivative was based on the following criteria: the length of the verbs (the shorter verb is likely to be the base one; e.g. dát 'to give.pf' > dávat 'to give.impf' in (8)), their semantic complexity (the derivative is semantically richer than the base verb; štékat 'to bark. impf' > štěknout 'to bark.pf' in (6b)) ${ }^{10}$ and/or corpus frequency (the base verb is expected to be more frequent than its derivative; skočit 'to jump.pf' > skákat 'to jump.impf' in (3a)). ${ }^{11}$ See Fig. 1 for a sample structure.

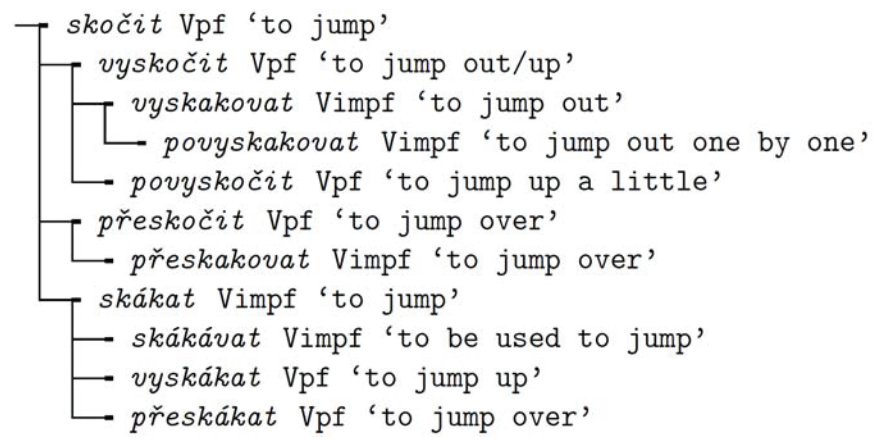

Figure 1. A simplified set of verbs of jumping organized according to the adopted criteria in DeriNet

\section{Conclusions}

In the paper, some issues of the long-standing debate over the category of verbal aspect in Czech were reopened in order to clarify the theoretical background for our data-based research into verb-to-verb derivation in Czech.

10 The perfective štěknout refers to the action as a one-spot event.

11 This expectation is based on previous works (Sambor 1975, Furdík 1978, Panocová 2017) and was supported by a pilot study on non-verbal data in DeriNet. The frequency ratio of skočit to skákat is 10:7 in the SYNv6 corpus (Křen et al. 2017). 
We argue for the grammatical account of the category of aspect seeing it as a complex of inflectional meanings formally marked by derivational affixes in Czech verbs. As there are no reliable criteria to recognize which verbs form an aspectual pair and, moreover, which of the aspectual counterparts might be considered the unmarked member (and thus the representative item of the whole paradigm), it was not feasible to separate formation of pure aspectual pairs from other types of verb-to-verb derivation in Czech when facing authentic language material.

The analysis was then reflected in the compilation of a simple set of rules which were used for organization of more than 50 thousand verbs into comparable structures in the DeriNet database. Semantic labelling of the structures, which is planned as a next step in the research, will involve semiautomatic assignment of aspectual pairs with a specific label. The verbal data in DeriNet then should serve as a very large, coherently annotated language resource that can be searched by different criteria.

\section{Acknowledgement}

This work was supported by the Grant No. GA16-18177S of the Czech Science Foundation. It has been using language resources developed, stored, and distributed by the LINDAT/CLARIN project of the Ministry of Education, Youth and Sports of the Czech Republic (project LM2015071).

\section{Bibliography}

BAUER L., 1997, Derivational paradigms, in G. Booij - J. van Marle (eds.), Yearbook of Morphology 1996, Dordrecht: Kluwer, pp. 243-256.

BEDna Ř́́KovÁ B., 2009, Slovo a jeho konverze, Olomouc: UPOL.

Blevins J. P., 2016, Word and Paradigm Morphology, Oxford: Oxford University Press.

Bloch-Trojnar M., (2013), The mechanics of transposition. A study of action nominalisations in English, Irish and Polish, Lublin: Wydawnictwo KUL.

BogusŁawski A., 2003, Aspekt i negacja, Warszawa: Takt.

BogusŁawski A., 2014, A brief account of a negation theory of the Slavonic verbal aspect, in Time and Temporality in Language and Human Experience, Frankfurt am Main: Peter Lang, pp. 210-240. 
Boolj G. E., 2008, Paradigmatic morphology, in B. Fradin (ed.), La raison morphologique. Hommage á la mémoire de Danielle Corbin, Amsterdam: Benjamins, pp. 29-38.

Boorj G. E. et al., 2000, Morphology. An International Handbook on Inflection and Word-Formation, Volume 1, Berlin - New York: Walter de Gruyter.

Bybee J. L. et al., 1994, The evolution of grammar: Tense, aspect and modality in the languages of the world, Chicago: The University of Chicago Press.

Comrie B., 1976, Aspect, Cambridge: Cambridge University Press.

CvrčEK V. et al., 2010, Mluvnice současné češtiny 1, Praha: Karolinum.

DAнL Ö., 1985, Tense and Aspect Systems, Oxford: Blackwell.

DANEŠ F., 1971, Pokus o strukturní analýzu slovesných významů, Slovo a slovesnost 32, s. $193-207$.

Dickey S. M. - JANDA L. A., 2015, Slavic Aspectual Prefixes and Numeral Classifiers: Two Kinds of Lexico-Grammatical Unitizers, Lingua, 168, pp. 57-84.

Dokulil M., 1962, Tvoření slov v češtině 1: Teorie odvozování slov, Praha: Nakladatelství ČSAV.

Eckert E., 1984, A Contrastive Study of Czech and Russian Aspect, PhD Thesis, Berkeley: University of Berkeley.

Esvan F., 2007, Vidová morfologie českého slovesa, Praha: NLN.

Esvan F., 2014, Tipologia e inventario dei verbi con prefisso vuoto in ceco, in A. Bonola et al. (eds.), Studi italiani di linguistica slava. Strutture, uso e acquisizione, pp. 47-56.

Filip H., 2012, Lexical Aspect, in R. I. Binnick (ed.), The Oxford Handbook of Tense and Aspect, Oxford: Oxford University Press, pp. 721-751.

FILIPEC J. et al., 1998, Slovnik spisovné češtiny pro školu a veřejnost. 2., opravené a doplněné vydání, Praha: Academia.

FuRdík J., 1978, Slovotvorná motivovanost’ slovnej zásoby v slovenčine, in: J. Mistrík (ed., Studia Academica Slovaca 7. Bratislava: Alfa, s. 103-115.

GrZegorCZyKowa R. et al. (eds.), 1984, Gramatyka wspótczesnego języka polskiego. Morfologia, Warszawa: IJP Państwowe Wydawnictwo Naukowe.

Grepl M. et al., 2000, Př́ruční mluvnice češtiny, Praha: NLN.

HaJIČ J. - Hlaváčová J., 2013, MorfFlex CZ, LINDAT/CLARIN digital library at Institute of Formal and Applied Linguistics, Charles University in Prague, http://hdl.handle.net/11858/00-097C-0000-0015-A780-9

HavráneK B. et al., 1960-1971, Slovník spisovného jazyka českého, Praha: Academia.

IsAČENKO A. V., 1960a, Grammatičeskij stroj russkogo jazyka v sopostavlenii s slovackim: morfologija, č. 2, Bratislava: Izdatel'stvo Slovackoj akademii nauk.

IsAČENKo A. V., 1960b, Slovesný vid, slovesná akce a obecný charakter slovesného děje, Slovo a slovesnost 21, s. 9-16. 
JAKobson R., 1971, Selected Writings, Vol. 2, The Hague: Mouton.

JANDA L. A. - LyashevsKayA O., 2011, Grammatical profiles and the interaction of the lexicon with aspect, tense, and mood in Russian, Cognitive Linguistics 22:4, pp. 719-763.

JiNDRA V., 2008, Vývojová dynamika obouvidových sloves cizího původu na základě korpusových dat, Slovo a slovesnost 69, s. 192-210.

KarcevskiJ, S., 1927, Système du verbe russe, Praha: Legiografie.

KomÁreK M., 1984, Prefixace a slovesný vid (K prefixům prostě vidovým a subsumpci, Slovo a slovesnost 45, s. 257-267.

Komárek M., 2006, Př́spěvky k české morfologii, Olomouc: Periplum.

Komárek M. et al., 1986, Mluvnice češtiny 2. Tvarosloví, Praha: Academia.

KopečnÝ F., 1962, Slovesný vid v češtině, Praha: Academia.

KŘEN M. et al., 2017, SYN corpus, version 6 from Dec. 18, 2017. Prague: Institute of Czech National Corpus, Faculty of Arts; http://www.korpus.cz

KučERA H., 1983, Semantic Model of Verbal Aspect, in: American Contributions to The Ninth International Congress of Slavists 1, Linguistics, pp. 171-184.

KuryŁowicz J., 1932, Pochodzenie slowiańskich aspektów czasownikowych, in Sbornik praci I. sjezdu slovanských filologů v Praze II, Praha: Výbor I. sjezdu slovanských filologů, s. 572-576.

Kuznetsova J. - Sokolova S., 2016, Aspectual triplets in Russian: semantic predictability and regularity, Russian Linguistics, 40:3, pp. 215-230.

Lopatková M. et al., 2017, Valenční slovnik českých sloves Vallex, Praha: Karolinum.

MasLov J. S., 1959, Glagol'nyj vid v sovremennom bolgarskom literaturnom jazyke (značenije i upotreblenije), in: Voprosy grammatiky bolgarskgo literaturnogo ja$z y k a$, s. 157-312.

Mathesius V., 1947, Čeština a obecný jazykozpyt, Praha: Melantrich.

MeL’ČUK I. A., 1994, Cours de morphologie générale, Vol. 2, Montréal: Presses de l'Université de Montréal.

NĚMEC I., 1958, Genese slovanského systému vidového, Praha: Nakl. ČSAV.

NÜBLER N., 1992, Untersuchungen zu Aktionsart und Aspekt im Russischen und Tschechischen, Regensburg: Roderer.

NüBLER N. et al., 2017, Vid. In P. Karlík et al. (eds.), CzechEncy - Nový encyklopedický slovník češtiny, https://www.czechency.org/slovnik/VID

Panevová J. et al., 1971, Čas a modalita v češtině, Praha: Univerzita Karlova.

Panocová R., 2017, Internationalisms with the Suffix -ácia and their Adaptation in Slovak, in Proceedings of the Workshop on Resources and Tools for Derivational Morphology (DeriMo), Milan: EDUCatt, pp. 61-72. 
Poldauf I., 1954, Spojování s předponami při tvoření dokonavých sloves v češtině, Slovo a slovesnost $15, \mathrm{s.}$ 49-65.

Poldauf I., 1964, Souhrnný pohled na vid, Slovo a slovesnost 25. s. 46-56.

SAmbor J., 1975, O stownictwie statystycznie rzadkim, Warszawa: Państwowe Wydawnictwo Naukowe.

Smith, C. S., 1991, The Parameter of Aspect, Dordrecht: Kluwer.

DE Swart H., 2012, Verbal Aspect, in R. I. Binnick (ed.), The Oxford Handbook of Tense and Aspect, Oxford: Oxford University Press, pp. 752-780.

Š́evČíková M. - ŽAвоKRTSKÝ Z., 2014, Word-Formation Network for Czech, in Proceedings of the 9th Language Resources and Evaluation Conference, Paris: ELRA, pp. 1087-1093.

ŠteKauer P. et al., 2012, Word-Formation in the World's Languages, Cambridge: Cambridge University Press.

ŠTícha F. et al., 2013, Akademická gramatika spisovné češtiny, Praha: Academia.

Uher F., 1987, Slovesné předpony, Brno: Univerzita J. E. Purkyně.

VendLer Z., 1957, Verbs and Times, The Philosophical Review 66, pp. 143-160.

Verkuyl H. J., 1993, A Theory of Aspectuality. The Interaction between Temporal and Atemporal Structure, Cambridge: Cambridge University Press.

Wiemer B. - SerŽAnt I. A., 2017, Diachrony and typology of Slavic aspect: What does morphology tell us? In W. Bisang - A. Malchukov (eds.), Unity and diversity in grammaticalization scenarios, Berlin: Language Science Press, pp. 239-307. DOI:10.5281/zenodo.823246

WierzBicKa A., 1967, On the semantics of the verbal aspect in Polish, in To Honor Roman Jakobson. Essays on the Occasion of His Seventieth Birthday, The Hague: Mouton, pp. 2231-2249.

ZikovÁ M., 2015, Morfonologické alternace v současné češtině, in O. Uličný (ed.), Preliminária k moderní mluvnici češtiny, Olomouc: UPOL, s. 177-201.

\section{Odvozování českých sloves a kategorie vidu}

\section{(shrnutí)}

Příspěvek se zabývá změnami v kategorii slovesného vidu, k nimž dochází během odvozování sloves od sloves v češtině. Po stručném shrnutí základních bodů aspektologických diskuzí nad videm českého slovesa je tvoření vidových protějšků prezentováno jako integrální součást derivace českých sloves. Ve shodě s tímto pohledem je kategorie vidu využita jako důležitý rys při modelování slovesné derivace v databázi zachycující derivační morfologii češtiny. V př́spěvku představujeme sadu kritérií, na jejichž základě byla slovesa $\mathrm{v}$ databázi organizována. 
